\title{
PERAN USER GENERATED CONTENT (UGC) INSTAGRAM PADA INDUSTRI MAKANAN
}

\author{
Desi Rubyanti \\ Irwansyah \\ Mahasiswa Magister Ilmu Komunikasi Universitas Indonesia \\ Staf Pengajar Ilmu Komunikasi FISIP UI \\ E-mail: desirubyanti@gmail.com,dr.irwansyah.ma@gmail.com
}

\begin{abstract}
Participatory web era allows more social media users' contribution to virtual communities, including creating User-Generated Content (UGC) for information sharing and communicating with other users. Awareness and informing concepts are brought by UGC content through discussion and/or posts can. In the food industry, UGC can act as Electronic-Word of Mouth with contributions and creations which are produced by users. Information about the function of organic information. Food industry players such as the Indomie brand see the opportunity to use UGC as an initial step for Electronic Word of Mouth in achieving its audience awareness goals. Using the phenomenological method, this qualitative study conducted data mining through informants who were directly involved in the UGC-based campaign on Indomie HypeAbis Chitato Taste of Roast Beef. Data shows sending trial products can build E-WOM organically and elevate share of voice through UGC that produced by Indomielovers. Strong UGC also needs to be supported by strong branding and motivation from users' prestige towards food trends to get recognition in the virtual community.
\end{abstract}

Keywords: UGC, Social Media, Instagram, Food Industry, E-Wom

\begin{abstract}
Abstrak
Pada era web partisipatif membuat pengguna media sosial memiliki keleluasaan dalam berkontribusi di komunitas virtual, termasuk mengunggah User Generated Content (UGC) dalam berbagi informasi dan/atau berkomunikasi dengan sesama pengguna. Dengan konten UGC melalui diskusi atau unggahan konten dapat memberikan efek kesadaran akan suatu informasi bagi orang yang dijangkau. Pada industri makanan, UGC sendiri dapat berperan sebagai Elektronik-Word of Mouth dengan adanya kontribusi dan kreasi yang dihasilkan oleh para pengguna. Sehingga ada fungsi menyebarkan informasi secara organik yang dapat berguna baik untuk pengguna lain maupun brand. Pelaku industri makanan seperti brand Indomie melihat peluang menggunakan UGC sebagai langkah awal E-WOM dalam mencapai objektif kesadaran khalayak. Dengan menggunakan metode fenomenologi, penelitian kualitatif ini melakukan penggalian data melalui informan yang terlibat langsung dalam kampanye berbasis UGC pada Indomie HypeAbis Chitato Rasa Sapi Panggang. Data dari informan menunjukan bahwa dengan memberikan produk yang akan diluncurkan di masa mendatang dapat membangun EWOM dan menaikan share of voice secara organik melalui UGC yang dihasilkan oleh Indomielovers. Hal ini tentu saja didukung oleh kehadiran branding yang kuat dan motivasi dari pengguna untuk terlihat mengikuti tren makanan sehingga mendapatkan pengakuan di komunitas virtual.
\end{abstract}

Kata kunci: UGC, Media Sosial, Instagram, Industri Makanan, E-Wom 


\section{PENDAHULUAN}

\section{Latar Belakang Masalah}

Seiring dengan perkembangan teknologi, beberapa tahun terakhir yang membuat kehidupan masing-masing individu terjadi juga di dunia digital (Khajuria, 2017). Pada rentang usia 16-64 tahun, riset HootSuite dan We Are Social menyatakan dalam "Global Digital Reports 2020" bahwa pengguna internet menghabiskan rata-rata 7 jam 59 menit dalam satu hari. Melihat dari porsi penggunaan internet di angka lebih dari $30 \%$, pelaku usaha di Indonesia seolaholah memiliki kewajiban untuk hadir di berbagai platform dimana target khalayak mereka berada. Salah satu komunikasi yang dapat dilakukan adalah dengan hadir di dunia digital dengan computer mediated communications (CMC). CMC di dunia digital digunakan untuk menjangkau total pengguna Internet sebanyak 175 juta dengan pengguna aktif media sosial sebanyak 160 juta pada tahun 2019 (We Are Social, 2020).

Platform media sosial merupakan produk dari Web 2.0, dengan tawaran interaktif tanpa batasan, yang juga disertai dengan kemudahan untuk berkontribusi seperti memberikan kesempatan bagi para pengguna untuk bersosialisasi dengan bereaksi, mengunggah, memberikan komentar dan berdiskusi pada platform (Mustonen, 2009). Komunikasi pada media sosial tidak hanya terjadi secara interpersonal atau individu kepada publik tetapi juga dapat terjadi kelompok ke kelompok (Khajuria, 2017) Adanya fasilitas tersebut, laporan GlobalWebIndex tahun 2018 mencatat penggunaan media sosial di Indonesia dapat menghabiskan rata-rata 195 menit atau tiga jam 15 menit dalam sehari (BBC, 2019).

Partisipasi dari pengguna internet juga didukung oleh berkembangnya ponsel pintar dengan berbagai fitur yang dimiliki seperti kamera dengan resolusi tinggi dan aplikasi editing sehingga UGC yang dihasilkan dalam bentuk video atau gambar dengan berbagai gaya. Bagi para pelaku usaha, komunitas virtual tertentu dapat membantu melakukan kampanye digital dan mendapatkan feedback dari khalayak secara instan. Hal ini sesuai dengan karakteristik industri 4.0 yakni adanya kecepatan sampainya data pengguna dalam wujud feedback secara online (Stevanov et al., 2017). Salah satu feedback yang didapatkan dari komunitas virtual adalah dengan melihat kepada konten User Generated Content (UGC) yang diunggah baik berupa teks, video maupun foto. Sama seperti komunitas lainnya, aset UGC tersebut dapat menjadi 
sumber pengetahuan untuk memahami lebih jauh mengenai tren dan perilaku konsumen, memunculkan perspektif baru bagi para pelaku industri dan berkomunikasi langsung dengan target khalayak yang lebih luas (Dahlander et al., 2008; Mustonen, 2009; Sawhney et al., 2005). Biasanya, untuk menarik minat pengguna media sosial untuk berinteraksi dan menghasilkan UGC, maka pelaku industri memberikan stimulus berupa pertanyaan atau kompetisi yang menarik para pengguna media sosial untuk mencoba berinteraksi dengan brand terkait.

Survey yang dijalankan oleh Offerpop menyatakan bahwa $85 \%$ konsumen menilai konten UGC lebih menarik perhatian daripada konten sponsor atau terafiliasi dengan satu brand tertentu. Studi terdahulu dari Rayinda, (2019) menemukan bahwa konten UGC yang di unggah memberikan pengaruh kepada tren makanan yang populer di kalangan Indonesia. Aktivitas berbagi informasi dan pertukaran ide lewat teks, menghasilkan terjadinya fenomena electronic word-ofmouth (eWOM) secara alami baik datang dari praktisi komunikasi profesional, pengguna dan endorser. E-WOM terjadi melalui berbagai UGC dan review pengguna media sosial, maka pengguna khususnya komunitas foodie akan berlomba untuk mencoba yang pada akhirnya tercipta sebuah tren (Rayinda, 2019). Walaupun tidak semua UGC dapat menjadi strategi komunikasi bagi para praktisi, namun konten organik dinilai memiliki nilai kejujuran yang lebih tinggi tanpa ada motif ekonomi. Hal ini juga berkaitan dengan fitur pencarian media sosial melalui nama akun atau hashtag tertentu, pengguna akan melihat unggahan UGC berisi informasi yang berasal dari pengguna lain. Jenis informasi yang dibagikan pada UGC, menurut Panahi, Watson dan Patridge (2012) adalah berupa tacit knowledge yang didefinisikan sebagai pengetahuan berdasarkan pengalaman, sejarah, wawasan, keahlian dan kepercayaan personal yang ada pada satu individu. UGC merupakan salah satu komponen yang hadir secara alami pada media sosial. Berbeda dengan mencari informasi, yang dilakukan di Internet melalui mesin pencarian, hasil yang didapat dengan menggunakan kata kunci tertentu telah dimanfaatkan oleh para advertiser atau marketer sehingga akan muncul situs korporasi (Blackshaw \& Nazzaro, 2006).

Fenomena UGC sebagai strategi komunikasi e-WOM juga terjadi di aplikasi sosial media populer ke-lima versi 
We Are Social (2020). Seiring dengan bertambahnya pengguna Instagram di Indonesia, maka produksi UGC akan semakin banyak. Instagram memfasilitasi pengguna untuk berkreasi melalui dua produk. Aplikasi yang diluncurkan pertama kali pada tahun 2010 oleh Kevin Systrom ini memiliki produk Instagram Feed dan Instagram Story. Keduanya sama-sama terdapat format gambar dan video, namun unggahan di Instagram Story akan hilang dalam jangka waktu 24 Jam. Saat ini menurut NapoleonCat menyatakan terdapat 62 juta pengguna Instagram di Indonesia (2020). Popularitas kategori makanan ada di peringkat ketiga (43\%) setelah kategori travel (45\%) dan musik (44\%) sesuai dengan data Facebook (2019). Fenomena mengunggah foto makanan pada Instagram bukanlah suatu tren yang baru, pencarian untuk hashtag \#food saja sudah mencapai 370 juga unggahan. Fenomena penggila makanan juga terjadi di Indonesia, bahwa secara aktif komunitas ini memproduksi konten semenarik mungkin dengan tujuan mempengaruhi dan membuat khalayak membeli makanan tersebut (Rayinda, 2019). Sebagai makhluk sosial yang membutuhkan validasi lingkungan sekitar, tidak jarang produksi konten di komunitas foodie seperti sebuah kompetisi dan hal tersebut merupakan kebanggaan tersendiri. Tentu saja tidak jarang dari motif berbagi, produk UGC dapat menjadi satu penghasilan di media sosial, seperti akunakun kuliner yang memang dijadikan referensi untuk para pengguna media sosial sekaligus berperan sebagai endorser bagi pelaku industri.

Kesempatan untuk memanfaatkan UGC sebagai strategi komunikasi digital tidak dilewatkan oleh salah satu perusahaan terbesar di industri makanan, PT Indofood CBP Sukses Makmur dalam mengembangkan kehadiran salah satu brand terbesar yang dimiliki, Indomie, di dunia digital. Memiliki brand equity yang kuat, Indomie menjadi dinobatkan sebagai "The Best Instant Ramen In The World" versi LA Times (2019). Brand yang telah hadir sejak tahun 1972 mulai aktif di dunia media sosial sejak tahun 2015. Melansir dari Mix (2017), sejak hadir di dunia digital penggunaan platform digital oleh Indomie tidak jarang melibatkan konsumen, seperti ulang tahun Indomie ke-40 dengan menyelenggarakan kontes jingle di media sosial Youtube pada tahun 2017. Apabila melihat pencarian hashtag untuk kata kunci \#indomie saja sudah dapat ditemukan 513 ribu konten yang diunggah. Indomie pada praktiknya seringkali melakukan kegiatan repost di 
Instagram dan mendapatkan lebih banyak like dibandingkan konten yang diproduksi sendiri. Tentu saja pihak media sosial dari agensi yang ditunjuk, OgilvyOne, telah mendapatkan izin dari pemilik UGC.

Peluncuran di dunia digital seringkali menemukan kendala terbesar yakni kebocoran produk di media sosial. Bahwa pada terdapat dua kebocoran besar yang terjadi untuk varian Indomie Telur Asin dan Indomie HypeAbis Ayam Geprek. Indomie Telur Asin adalah salah satu varian premium yang dijadwalkan untuk muncul di pasaran pada bulan September harus maju untuk muncul di digital pada bulan Agustus karena unggahan UGC bungkus Indomie dari akun @_sellygempal pada akhir bulan Juli 2018 (Grid, 2018). Setelah itu kebocoran produk Indomie HypeAbis Ayam Geprek, produk pertama dari lini HypeAbis, di media sosial terjadi kembali pada Januari 2019 seminggu sebelum peluncuran produk. Kebocoran ini diakibatkan oleh unggahan beberapa media yang tidak melewati persetujuan dari pihak Brand maupun Agensi sehingga sebelum dihapus konten tersebut sudah dilihat beberapa pengguna dan menghasilkan suatu perbincangan di media sosial. Melihat dari kedua kejadian tersebut, Tim Indomie bersama Agensi menyusun strategi komunikasi Instagram
e-WOM melalui UGC untuk menyebarkan informasi mengenai produk Indomie HypeAbis Rasa Chitato Ayam Panggang (IHAC), varian premium Indomie sebagai hadiah ulang tahun untuk makanan ringan Chitato.

Pada strategi komunikasi digital ini, Indomie memulai dengan melibatkan partisipasi “Indomielovers", panggilan khalayak untuk Indomie. Indomielovers memiliki kesempatan untuk berkreasi mengenai kado ulang tahun yang ke-30 untuk Chitato. Fitur Questions and Answers digunakan untuk Indomielovers berpartisipasi. Dilansir dari Grid, ide dari UGC tersebut berupa Payung, Jaket, Tumblr hingga Bola (Grid, 2019). Dari berbagai respon yang ada, tidak sedikit yang menyebutkan Indomie Rasa Chitato. Dengan melakukan sortir kepada responden kado Indomie tersebut, terpilih 100 Indomielovers yang akan dikirimkan 2 buah Indomie HypeAbis Chitato rasa Ayam Panggang, dua minggu sebelum produk tersebut muncul di pasaran. Hal ini tentu saja menjadi tanda tanya bagi para Indomielovers mengenai keberadaan produk baru tersebut. Diluncurkan pada minggu pertama Mei 2019, Grid (2019) mencatat Axton Salim sebagai Chief Marketing Officer mengumumkan secara resmi mengenai produk Indomie 
HypeAbis Chitato melalui platform Instagram.

Peran UGC pada media sosial telah dibahas dalam beberapa penelitian sebelumnya seperti pada penelitian literature review oleh (Rayinda, 2019) "Pengaruh User Generated Content Terhadap Perilaku Para Foodie Pengguna Media Sosial" yang menemukan bahwa unggahan UGC para Foodie mempengaruhi tren makanan populer di kalangan masyarakat Indonesia. Selain itu, peran UGC pada media sosial juga dibahas dalam sektor pariwisata, yakni penelitian yang dilakukan oleh Germon et al., 2017) yang berjudul "Analyzing User Generated Content on Instagram: the Case of Travel Agencies" yang melihat UGC membawa nilai keterlibatan pengguna lebih banyak pada komunitas travelling. Melihat berbagai penelitian berfokus dari perspektif pengguna ataupun konsumen, Penelitian ini akan berfokus dalam memberikan kontribusi pentingnya UGC pada E-WOM dari sisi pelaku industri dengan rumusan masalah: "Bagaimana peran User Generated Content sebagai Electronic Word Of Mouth pada platform Instagram bagi pelaku industri makanan?”. Sehingga penelitian ini bertujuan untuk melihat bagaimana pelaku industri makanan melihat UGC yang ada di
Instagram dapat berperan menjadi alat EWOM untuk membantu memasarkan produk mereka secara digital.

\section{Tinjauan Pustaka}

Pada tahun 1665, Journal des Scavans dan Philosophical Transactions of the Royal Society mempublikasikan berbagai surat mengenai penemuan penelitian yang ditujukan untuk menyebarkan berita mengenai penemuan penelitian, yang digunakan sebagai salah satu contoh pertama dari User Generated Content (UGC) (Lobato et al., 2012). Seiring dengan perkembangan zaman dan teknologi, seperti yang dikatakan oleh (Lobato et al., 2012) dalam penelitiannya UGC dianggap memiliki komponen yang dapat menentukan ranah tersebut informal atau formal seperti contohnya fasilitas dari media komersial atau organisasi publik, regulasi yang mengatur hingga kepada konteks yang diberikan oleh pemilik UGC tersebut. Dalam dunia digital, Interactive Advertising Bureau (2008) mencatat bentuk UGC pada awal kemunculan internet, lebih khususnya di platform digital adalah oleh Usenet dan Prodigy, yang memfasilitasi diskusi dan komentar antara member dan pengguna. Perkembangan ini terus berlanjut dari 
adanya ulasan, blog, Wikis, hingga UGC dan jaringan iklan sosial (IAB, 2008).

Dari penelitian sebelumnya, ditemukan beberapa definisi UGC yang dikembangkan oleh para ahli. Melansir dari penelitian Malthouse et al. (2016) yang berjudul "Evidence that User Generated Content that Produces Engagement Increases Purchase Behavior" bahwa ada berbagai definisi UGC yang dapat diklasifikasikan: (1) Perpindahan peran; (2) Karakteristik; dan (2) Consumer' Online Brand Related Activities. Klasifikasi pertama adalah para peneliti berfokus kepada perpindahan dari computer generated content kepada user generated content seperti contohnya Daugherty et al. (2008) dan Interactive Advertising Bureau mengungkapkan bahwa UGC atau bisa juga disebut dengan Consumer-Generated Media (CGM) adalah konten yang diproduksi oleh publik dan bukan berasal dari profesional yang didistribusikan di Internet, walaupun hanya berbentuk komentar. Maka dalam hal ini UGC pada perkembangan teknologi dapat didefinisikan sebagai konten yang terdapat pada konteks luas, internet, pada konteks sempit, media sosial, yang diproduksi oleh pengguna dimana mereka bukanlah seorang komunikasi profesional atau institusi media (Wang \& Rodgers, 2010).

Tipe definisi kedua adalah berdasarkan karakteristik seperti yang diungkapkan oleh Organisation for Economic Co-operation and Development (2007) pada jurnal Participative Web: User Created Content, terdapat tiga karakteristik yang melekat pada UGC: (1) Diunggah dan dapat diakses oleh publik, sehingga surat elektronik atau e-mail dan pesan instan antar dua orang tidak termasuk; (2) Memasukan nilai dari user atau pengunggah secara kreatif, dapat berupa kolaborasi sehingga mengunggah ulang konten orang lain atau profesional bukan termasuk UGC; (3) Tidak untuk ranah profesional dan bisnis, tujuan dan motivasi lebih kepada popularitas, prestise atau sebagai bentuk ekspresi. Faktor ketiga adalah Consumer' Online Brand Related Activities atau yang disebut dengan COBRAs, yang dikembangkan oleh Muntinga et al., (2011). Menurut Muntinga et al., (2011), ada tiga dimensi dari level rendah ke tinggi mengenai aktivitas pengguna media sosial yang berkaitan dengan aktivitas brand: (1) Konsumsi: level minimal yang dilakukan oleh pengguna adalah melihat, mendengar, mengikuti diskusi konten yang terkait dengan aktivitas brand; (2) Kontribusi: 
level menengah dari aktivitas pengguna berupa berkontribusi seperti memberikan komentar pada forum atau media sosial yang berkaitan dengan brand; (3) Kreasi: pada level ini, pengguna secara aktif membuat konten berkaitan dengan aktivitas brand sampai kepada level kreativitas seperti menulis ulasan di blog atau media sosial, mengunggah video berkaitan dengan brand. Dalam hal ini, aktivitas UGC dimulai pada level kontribusi dan kreasi.

Media sosial merupakan salah satu aplikasi yang memiliki komunitas berbasis internet dengan fondasi ide dan teknologi web 2.0, menawarkan pengguna untuk memproduksi berbagai UGC (Kaplan \& Haenlein, 2010). UGC pada media sosial terjadi ketika muncul konsep perceived interactivity yang memiliki dua jenis dimensi berbeda: (1) Interaksi antar manusia; dan (2) interaksi manusia dengan informasi. Kedua karakteristik ini menunjukan pemakaian sosial media oleh para pengguna memiliki tujuan sosial dan juga kognitif, yang dilakukan dengan computer mediated communications (Lin \& Chang, 2018). Secara khusus, pertukaran informasi di media sosial dapat membantu sesama pengguna menemukan informasi yang relevan dan dianggap lebih berpengaruh dibandingkan dengan bias yang dihasilkan oleh para ahli komunikasi atau marketer (Hsiao \& Chuang, 2009).

Setelah mengetahui definisi dari UGC, maka penelitian ini juga perlu mengetahui motivasi dibalik pembuatan UGC. Rensink (2013)mengungkapkan pada penelitiannya mengenai motivasi dibalik seseorang mengunggah UGC adalah: (1) mencurahkan perasaan negatif; (2) sebagai bentuk peningkatan diri; (3) keuntungan sosial seperti memperluas jaringan dan eksistensi; (4) membantu pengguna lain; (4) memberikan peringatan kepada pengguna lain (3) membantu perusahaan tersebut. Dari jenis motivasi ini dapat diungkapkan bahwa UGC dapat bersifat negatif ataupun positif, maka pihak brand sendiri perlu mengamati bagaimana sentiment dari masing-masing UGC.

O’Hern \& Kahle (2013) mengungkapkan empat tipologi dari UGC pada jaringan sosial dalam lingkup: (1) Informasi: terdapat aktivitas proses pengguna dalam membuat konten baik memuji ataupun memberikan kritik mengenai suatu produk yang dapat menjangkau jutaan pengguna lain mengenai produk tersebut dan terdapat unsur word-of-mouth pada UGC yang mengakibatkan citra positif dan negatif dari suatu produk. Merujuk kepada eWOM 
adalah suatu bentuk pernyataan yang bersifat positif atau negatif yang dipublikasikan oleh konsumen atau calon konsumen terhadap suatu produk, perusahaan atau review yang dapat diakses oleh khalayak banyak khususnya pengguna internet (Hennig-Thurau \& Walsh, 2003); (2) Co-Communicating: Proses inisiatif yang dilakukan untuk diberikan kepada brand atau perusahaan yang seringkali disebut dengan user generated advertising biasanya melalui kontes yang hasilnya tergantung dari persyaratan, kreativitas, maupun citra dari perusahaan tersebut; (3) Co-Creating: Proses dimana pengguna dapat membuat suatu desain terkait dengan brand dan melakukan submisi untuk kompetisi yang mana desain terpilih akan diproduksi dan diluncurkan di masa depan, hasil dari UGC ini dapat bergantung kepada berbagai faktor salah satunya motivasi partisipan; dan (4) Pelopor: Dalam kategori ini, konsumen tidak membuat submisi kepada brand atau perusahaan, namun target khalayak diluar dari perusahaan tersebut. Maka unggahan UGC yang bersifat sukarela dan secara sadar dilakukan oleh konsumen tanpa motif membantu brand atau media mendapatkan suatu keuntungan. Salah satu peran UGC dalam media sosial bagi pelaku industri adalah dengan mendorong pengguna menggunakan hashtag kampanye tertentu, yang mana peran pengguna sebagai salah satu advertiser melalui UGC yang diunggah dapat terbentuknya e-WOM organik (Laestadius \& Wahl, 2017). Wang \& Rodgers (2010) mengungkapkan eWOM merupakan salah satu tipe UGC yang memiliki dua peran: memberikan umpan balik pada situs dan memberikan opini dengan memasukan konteks emosional untuk dibagikan di jaringan sosial. E-WOM dapat digunakan sebagai alat pemasaran yang efisien hanya saja bagaimana konsumen berbicara tentang produk mereka dan harus memahami eWOM serta bagaimana efek dari komponennya dan fitur yang ada dalam fitur tersebut (Wang \& Rodgers, 2010).

Peran lain dari UGC adalah peran afirmasi pada media sosial, sehingga ekspresi yang diwujudkan pada konten adalah bentuk dari identitas sosial yang menjadi tolak ukur reliabilitas dan popularitas pengguna media sosial. Studi terdahulu mengungkapkan bahwa penggunaan media sosial memiliki tujuan untuk mendapatkan pujian positif untuk kepuasan tersendiri (Svensson, 2011).

Melihat dari paparan literatur di atas, maka dengan memanfaatkan motivasi untuk mendapatkan pujian positif tersebut, 
UGC dapat berperan sebagai E-WoM, salah satunya untuk menyebarkan informasi dan menciptakan tren di antara pengguna media sosial. Dalam hal ini, konsep co-communication menjadi salah satu konsep yang paling menunjukan peran UGC sebagai E-WoM, lewat kreasi konten yang memberikan konteks kedekatan antara pengguna dengan brand di media sosial.

\section{METODE PENELITIAN}

Dalam melakukan analisis, pendekatan kualitatif akan digunakan dengan menggunakan metode fenomenologi. Dalam hal ini Moleong (2009) mengungkapkan metode penelitian fenomenologi memiliki tujuan untuk memahami bagaimana interpretasi dunia muncul pada suatu individu berdasarkan pengalaman subjek penelitian. Penulis menggunakan metode tersebut untuk memperoleh informasi dari subjek penelitian yakni bukan dari sisi pengguna namun dari sisi pelaku industri. Penelitian ini dilakukan dengan wawancara tidak terstruktur dengan informan kunci, Account Manager Agensi Media pada saat proyek Indomie Chitato, NV dan Account Manager Agensi Digital Ogilvy, Inisial FV melalui pesan instan WhatsApp. Pemilihan informan kunci bertujuan untuk melihat konstruksi dari informan yang berpartisipasi langsung dalam menyusun strategi komunikasi. Menurut Creswell (2013) penelitian kualitatif menjadikan peneliti sebagai instrumen kunci dengan teknik pengumpulan data seperti wawancara dan pengumpulan dokumen. Dalam artikel ini, peneliti menjadi instrumen kunci dan melakukan penggalian data.

Wawancara melalui pesan WhatsApp karena keterbatasan waktu yang dimiliki oleh narasumber, dan menurut (Kaufmann \& Peil, 2020) mengumpulkan data melalui pesan instan WhatsApp dapat membuat informan merasa lebih kasual. Data sekunder dikumpulkan dengan mengumpulkan data jurnal yang berkaitan dengan konsep ditambah dengan publikasi diluar jurnal ilmiah yang dapat menjadi data pendukung terkait fenomena yang dianalisis (Ingrosso, 2015). Setelah itu data dianalisis menggunakan analisis tematik. Analisis tematik dijalani dengan identifikasi data, analisis data, lalu menyelaraskan pola-pola yang terdapat dalam data dan disajikan secara detail (Braun dan Clarke, 2013).

\section{PEMBAHASAN}

Hadirnya media sosial membuat para pelaku industri makanan memiliki 
alternatif untuk menjangkau konsumen, tanpa terbatas wilayah. Komunikasi yang dilakukan pada media sosial sebagai komunitas virtual juga dapat membawa komunikasi efektif seperti: (1) reputasi; (2) awareness; dan (3) peringkat pada situs pencarian. Namun, adanya perluasan konteks komunikasi yang mencakup anonim, pertukaran eWOM di komunitas membuat sebuah pertanyaan mengenai kredibilitas informasi yang didapat (Tham et al., 2013). Sebagai brand mie instan populer di Indonesia maupun dunia, maka Indofood yang sudah berdiri 1972 tidak ingin ketinggalan untuk melakukan komunikasi melalui platform media sosial, dengan membuat akun Instagram dan Facebook sebagai salah satu usaha untuk dekat dengan target khalayaknya. Peluncuran koleksi HypeAbis dari Indomie juga tidak terbatas pada produk Indomie saja, namun adanya koleksi nonmakanan yang membuat antusiasme dari Indomielovers sangatlah besar. Seperti contohnya adalah koleksi ulang tahun Indomie ke 45 yang dilengkapi dengan tas tangan dan hal tersebut menjadi salah satu item yang dicari pada tahun 2017 lalu.

Narasumber FV dan NV merupakan rekan antar agensi ketika kampanye IHAC ini berjalan. FV adalah seorang Senior Account Manager di Agensi Ogilvy \&
Mather yang telah lama berkecimpung di bidang periklanan selama lebih dari tujuh tahun dalam menangani berbagai klien periklanan termasuk industri makanan. Sedangkan NV, memulai karirnya di dunia agensi media digital berdama I-DAC menangani kampanye digital berbagai industri makanan selama tiga tahun. NV sendiri sudah dua tahun ini menjadi Senior Digital Planning Manager.

\section{Motivasi Pengguna Mengunggah UGC}

\section{Keuntungan Sosial dan Peningkatan}

\section{Diri}

Dengan melihat fenomena UGC tersebut, NV sendiri menyadari bahwa UGC yang diunggah atau dikirimkan oleh para Indomielovers ini bukanlah tanpa alasan. Inisiatif tersebut dapat dibangun karena beberapa alasan. Pertama, karena brand tersebut memiliki kekuatan sosial yang mampu ditunggangi untuk menaikan popularitas. FV juga menyebutkan, dengan mengunggah suatu hal yang sedang tren dan kekinian, maka seseorang akan merasa dianggap beruntung oleh komunitasnya karena telah mendapatkan sesuatu yang eksklusif. Yap et al. (2013) menyebutkan motivasi ini berkaitan dengan keuntungan sosial yang bertujuan menunjukan posisinya kepada komunitas di sekitarnya. Hal ini juga dapat bersinggungan dengan 
konsep FoMO yang didefinisikan oleh Przybylski et al. (2013) sebagai fenomena kekhawatiran ketika seseorang mendapatkan pengalaman yang dirasakan orang lain. Dalam hal ini, konsep FoMO muncul karena adanya pengaruh normatif pada UGC. Dengan melihat kepada seseorang yang memproduksi UGC secara konsisten di satu komunitas, maka penerima UGC tersebut memiliki keinginan untuk berpartisipasi juga agar dianggap bagian dalam komunitas.

Yang kedua, menurut NV adalah bagaimana brand tersebut memiliki relevansi dengan kehidupan khalayak atau dapat menjadi penggambaran jati diri dan gaya hidup dari khalayak tersebut. Relevansi ini berkaitan dengan momen yakni seperti tren makanan yang ada di sekitar mereka ataupun produk tersebut baru mengeluarkan koleksi diluar makanan yang desainnya sesuai dengan selera khalayak tersebut dan dapat dijadikan sebagai cara ekspresi diri. Terlebih lagi, F mengungkapkan inovasi Indomie juga mulai diawasi oleh kompetitor dan mereka mencoba membuat tren baru sehingga relevansi brand terhadap target khalayak merupakan suatu hal yang sangat penting.

Yang ketiga adalah ketika UGC yang diunggah dapat membawa nilai tertentu seperti contohnya ketika adanya giveaway tentu saja hal ini akan membawa peluang menjadi pemenang. Seperti pada akun Instagram @indomie mengenai aktivasi \#RunningMieChallenge sebagai salah satu bagian kampanye IHAC sendiri menghasilkan UGC berupa 861 komentar di akun@indomie dan 238 unggahan Indomielovers di akun milik mereka sendiri dengan hashtag tersebut. Indomielovers merasa dengan ikut dalam kompetisi tersebut sepadan dengan kesempatan menang dan bertemu dengan selebritis idola asal Korea Selatan, Grup Running Man. Kategori Indomielovers ini memiliki pandangan bahwa UGC yang mereka unggah di akun masing-masing haruslah sepadan dengan nilai yang dituju, yakni hadiah giveaway tersebut. Partisipasi ini juga dapat terbentuk dengan motivasi peningkatan diri di lingkungan sehingga dianggap kredibel dan mengekspresikan kalimat-kalimat persuasif kepada sesama pengguna Yap et al. (2013).

\section{Membantu Perusahaan}

Indomielovers, panggilan untuk para target khalayak tersebut terbukti tidak hanya pada tahap berkontribusi dalam setiap aktivasi digital yang diadakan. Dilansir dari Tirto, bahwa target khalayak mereka seringkali membuat kreasi melalui UGC yang diunggah di media sosial tanpa 
ada maksud komersil atau submisi. Penerimaan Indomie di kehidupan khalayak Indomie terlihat dari unggahan Facebook Kementerian Humor Indonesia mengenai "Tipe-Tipe Pemeluk Agama Indomie" yang dibagikan lebih dari 13.000 kali yang membagi kategori penikmat Indomie melalui cara penyajian mereka (Tirto, 2019). Bukti lain dari penerimaan Indomie di komunitas virtual adalah melalui akun Twitter@AgamaIndomie yang membuat Indomie sebagai salah satu aliran kepercayaan yang diikuti oleh para pecinta Indomie. Dilihat dari yang dilakukan tidak dilakukan atas dasar submisi kepada brand, maka hal ini dapat dilihat sebagai bentuk pelopor seperti yang diungkapkan oleh O'Hern \& Kahle (2013) bahwa inovasi yang diberikan oleh Indomielovers bukan inisiatif dari brand namun inisiatif dari Indomielovers sendiri.

Dalam penelitian Rensink (2013) dikatakan bahwa dengan puasnya konsumen terhadap suatu produk membuat mereka memiliki keinginan untuk membantu. Seperti contohnya adalah bagaimana Indomie membantu Klub Sepak Bola favorit mereka, dan komen yang ditunjukan adalah akan membeli Indomie sebagai wujud terima kasih karena telah menjadi sponsor dari bagian hidupnya. Hal ini menunjukan adanya kepuasan terhadap Indomie.

\section{Alasan Penggunaan UGC sebagai E- WOM}

FV tidak memungkiri bahwa indomielovers merupakan salah satu komunitas yang loyal terhadap brand. Ia juga mengatakan peran UGC ini penting untuk bentuk awareness yang paling awal untuk menjangkau khalayak lain secara organik untuk memunculkan rasa penasaran khalayak lain. Menggunakan UGC sebagai salah satu upaya selain bergantung kepada algoritma media sosial yang berubah-ubah membuat para praktisi seringkali kebingungan dengan angka yang disajikan tiap unggahan di akun brand berbeda. Maka melihat dari hal tersebut, F melihat adanya peluang untuk menjalankan strategi UGC, dengan tingkat jangkauan dan latar belakang yang berbeda. (Delafrooz et al., 2019) bahwa komunikasi antar teman dapat menjadi hal penting dalam melakukan konstruksi dan membantu informasi terkait brand tersebar di Instagram.

Ditambah lagi menurut NV peran UGC sebagai E-WOM semakin penting karena keragaman latar belakang Indomielovers mulai dari pengguna biasa media sosial hingga artis ataupun key opinion leader yang sering menjadikan 
Indomie sebagai komponen konten dalam momen tertentu terutama ketika ada produk baru yang diluncurkan. Dalam hal ini, diakui motivasi popularitas yang telah disebutkan sebelumnya digunakan sebagai salah satu strategi Indomie untuk melakukan pengiriman gerilya ke sejumlah Indomielovers. Dilansir dari JingDaily (2020), pelaku industri dapat memunculkan sifat FoMO dengan strategi komunikasi yang relevan dan sahih. Untuk mewujudkan hal tersebut, pelaku industri dapat memilih konten-konten yang dirasa relevan dengan target khalayak sehingga pesan yang sampai beresonansi. Salah satu strategi komunikasi adalah melalui UGC.

Pemilihan Instagram sebagai jaringan media sosial utama dalam menjaring UGC tersebut dikemukakan oleh NV karena Instagram sebagai bagian dari platform media sosial yang paling banyak diakses dan sebagai tolak ukur suatu konten dapat diterima atau tidak oleh masyarakat dapat terlihat dari keterlibatan dan jangkauannya di Instagram. Hal ini ada kaitannya dengan umpan balik yang didapatkan di Instagram dapat dengan mudah dilacak melalui hashtag atau akun.

\section{Peran Informasi}

Pada peluncuran IHAC sendiri, FV menyatakan objektif menjadi viral untuk produk ini sengaja dilakukan dengan cara organik. Karena produk ini adalah produk terbatas hanya tiga bulan diproduksi, maka biaya yang dikeluarkan juga tidak terlalu banyak seperti produk lainnya. Apabila selama ini kebocoran informasi produk sebelum peluncuran seringkali terjadi dan berakhir viral sebelum keluar pernyataan resmi dari pihak brand maka Felicia mengungkapkan strategi yang dijalankan adalah memberikan sesuatu mengenai Indomie yang bisa disebarkan secara organik oleh para Indomielovers. Brand Manager Indomie, Felicia Stephanie, juga menyatakan bahwa selama ini beberapa produk Indomie viral melalui kekuatan Indomielovers. Pada tahap ini terlihat peran UGC sebagai E-WOM yakni sebagai penyebar informasi yang kuat, berkaitan dengan brand tersebut. NV sendiri melihat bahwa dengan berbagai brand yang telah Ia tangani, tidak semua khalayak bisa dengan sukarela melakukan hal tersebut apabila tidak berkaitan dengan kehidupan sosial khalayak tersebut. Dalam hal ini, NV menyayangkan banyak brand yang memang memiliki kampanye serupa namun tidak memasukan unsur UGC menjadikan kampanye tersebut sama dengan brand lain dan terkesan sangat hard selling. Hal ini tentu saja berkaitan dengan nilai emosional yang dibawa setiap UGC akan berbeda dengan konten brand. 
Mohammad et al. (2020) mengungkapkan bahwa UGC yang sukses yakni yang membawa nilai-nilai yang berwujud maupun tidak berwujud, seperti sesuai dengan ekspektasi, penuh dengan informasi, menarik dan relevan yang mana berpengaruh terhadap keterlibatan pengguna lain.

Felicia juga mengungkapkan pentingnya peran UGC sebagai E-WOM sangat istimewa. Karena tidak semua brand yang kuat seperti Indomie dapat keistimewaan memiliki UGC yang banyak dari konsumen. Ia merasa dengan kehadiran UGC, brand dapat melihat seberapa banyak keterlibatan khalayak terhadap brand tersebut terutama di media sosial. Cara baru ini diterapkan setelah sebelumnya membayar sejumlah Key Opinion Leaders sebagai E-WoM di media sosial terutama Instagram sebagai platform utama untuk peluncuran produk baru Indomie HypeAbis. Hal ini sejalan dengan penelitian Selain untuk menunjukan adanya produk baru, peran UGC ini juga menyampaikan informasi mengenai kehadiran Indomie di toko online Tokopedia untuk pertama kalinya secara eksklusif, sehingga informasi yang dibawa oleh para Indomielovers melalui UGC ini sedikit banyak membawa dampak terhadap penjualan. Namun pesan bahwa
Indomie hadir di platform online sendiri seharusnya bisa saja diumumkan langsung oleh Indomie ataupun Tokopedia.

NV melihat peran UGC sebagai EWoM secara praktis terutama dalam menyampaikan informasi adalah sekaligus menghasilkan pemikiran dan rasa penasaran bagi pada pengikut UGC tersebut, hal ini dapat dilakukan dengan melakukan ulasan atau terlebih lagi dengan membangun tren kekinian dengan banyaknya UGC yang tersebar. Rasa ingin tahu dan penasaran yang besar menurut NV disebabkan oleh perhitungan dalam dunia digital. Ia mengungkapkan satu konten UGC di dunia digital akan menghasilkan diskusi di wordcloud diharapkan dapat menghasilkan dampak yang cukup besar dan konten di ekosistem digital dapat mempengaruhi hingga keputusan untuk membeli produk. Berkaitan dengan hal ini Yang \& Mutum (2015) mengungkapkan UGC juga dapat memberikan dukungan emosional kepada komunitas sehingga mereka dapat memutuskan sesuatu berdasarkan infromasi yang ditemukan di komunitas virtual. Dalam hal ini, fungsi informasi dapat meluas kepada pengambilan keputusan, tidak hanya sampai batas kesadaran akan adanya suatu produk atau tren yang terjadi. 


\section{Peran Co-Communicating}

Selain dari kontribusi Indomielovers melalui UGC yang kuat, Maka berdasarkan banyaknya UGC yang sudah pada tahap pelopor, sehingga ada atau tidaknya komunikasi dari brand, UGC Indomie akan selalu ada. Namun karena tingkat kreasi yang diberikan berbeda maka kualitas resolusi dan penampakan Indomie menjadi pertimbangan untuk diunggah ulang oleh pihak brand. Hal tersebut merupakan tantangan tersendiri karena jaminan kualitas dari kreasi Indomielovers sendiri ada diluar kontrol brand. Yang menjadi suatu kekhawatiran apabila hal tersebut dapat sedikit banyak berpengaruh kepada informasi yang disampaikan, baik dari segi gambar ataupun penggunaan diksi. Walaupun dalam penelitian terdahulu yang dikemukakan oleh Mohammad et al. (2020) menunjukan yang menjadi tolak ukur UGC yang baik bukan dari segi desain atau estetika melainkan UGC yang secara praktis dapat memberikan nilai emosional kepada pengguna lain. Namun NV juga mengungkapkan resiko lain dalam melakukan strategi UGC ini adalah komentar negatif yang dilontarkan tertangkap oleh khalayak yang apabila konten tersebut secara emosional diterima oleh pengguna lain dapat membawa bumerang dengan membawa reputasi buruk bagi brand. Menjadi brand yang sudah menjadi Top of Mind berarti menunjukan pesan dan informasi yang konsisten kepada konsumen di berbagai media dan hal ini perlu menjadi pertimbangan menggunakan UGC untuk membangun pesan-pesan tersebut secara halus (O’Hern \& Kahle, 2013).

Kendati dari tantangan yang dimiliki, FV percaya ketika fase yang dilakukan sudah sesuai dan branding Indomie yang kuat dapat membawa strategi UGC berfungsi sebagai bentuk praktis dari cocommunication, yang mana UGC Indomielovers berperan sebagai E-WOM untuk pengikut media sosial mereka, karena Indomie menggunakan akun Indomielovers secara tidak langsung untuk menyampaikan informasi mengenai peluncuran produk dan juga kehadiran IHAC di toko online. Memberikan kesempatan bagi para masyarakat turut serta juga salah satu strategi komunikasi yang akan berujung kepada eWOM dan berpotensi menimbulkan kepercayaan. Mulai muncul pada tahun 2000, Prahalad \& Ramaswamy (2000) mendefinisikan konsep serupa yang dinamakan cocreation sebagai fenomena peran konsumen dan pelaku industri berkolaborasi dan ada pada satu sisi yang 
sama, bukan sebagai konsumen-industri lagi. Dengan menetapkan pengguna atau khalayak sebagai spotlight utama dengan tetap memberikan penanaman ide di dalam konten yang ada di sosial media bahwa Ekhlassi dkk (2012) mengatakan dengan menggunakan pengalaman pengguna yang positif maka brand image akan semakin baik dan dapat digunakan untuk menangkal adanya sentimen negatif. Membuat pengguna bercerita dapat menumbuhkan advokasi dan akan membuat asosiasi brand dengan pengguna semakin dekat. Maka di masa depan kemungkinan yang terjadi adalah lebih banyaknya co-creation yang terjadi untuk membangun brand image di jaringan media sosial. Co-creation ini juga dapat ditonjolkan dengan berkolaborasi atau menyebarkan press release untuk membangun sentimen positif mengenai hubungan baik antara pelaku industrimasyarakat. Strategi Indomielovers berperan sebagai penyebar kesadaran akan kehadiran Indomie di dunia digital menjadi sangat menarik karena hampir $70 \%$ dari Indomielovers yang dikirimkan paket IHAC mengunggah di Instagram Stories dengan kreasi yang berbeda-beda. Disini mereka menandai Indomie dalam unggahannya dengan harapan dapat diunggah ulang.
Untuk menjalankan proses cocommunicating, menurut $\mathrm{NV}$ pemiliihan UGC juga berperan penting, Pemilihan Indomielovers sendiri dipilih berdasarkan: (1) dampak yang dapat diciptakan: Dampak yang dapat diciptakan secara kasat mata dapat dilihat dari bagaimana Ia melakukan unggahan di media sosial, apakah informasi yang Ia sampaikan jelas dan akun yang dipakai bukan akun khusus giveaway atau yang tidak jelas asal usulnya.; (2) jumlah pengikut: dengan melihat seimbangnya jumlah pengikut dan yang diikuti, maka dapat dilihat kredibilitas dari suatu akun tersebut, terlebih kalau Ia memiliki pengikut yang lebih banyak; dan apabila diperlukan; (3) Persentase keterlibatan antara Indomielovers dan teman-temannya: Hal ini dimaksudkan untuk melihat apakah Indomielovers tersebut memiliki kedekatan dengan teman media sosialnya sehingga pesan yang disampaikan memunculkan keterlibatan dan rasa penasaran di komunitasnya. O'Hern \& Kahle (2013) menyatakan walaupun program co-communication ini sebenarnya tergantung dari UGC yang ada di media sosial, namun pemilik brand dapat menentukan siapa saja yang dapat berpartisipasi untuk melakukan komunikasi dengan perusahaannya. 
Seperti mungkin perihal melakukan unggahan ulang dari kiriman cocommunicating.

\section{Kontribusi Kepada Penelitian}

Dalam penelitian sebelumnya menunjukan bahwa peran UGC oleh para komunitas pecinta makanan (foodie) dapat mempengaruhi tren makanan yang ada di Instagram (Rayinda, 2019). Hal ini seperti yang diungkapkan sebelumnya oleh NV, bahwa dalam membangun E-WOM akan membantu naiknya share of voice pada digital cloud. Dengan adanya UGC yang berperan sebagai penyebar informasi dan co-communicating, maka ada tiga keuntungan yang dimiliki:

Menyebarkan informasi terhadap produk yang dicapai melalui E-WOM secara organik (2) Dapat menangkal sentimen negatif melalui kreasi konten yang dimuat oleh para pengguna (3) Meningkatkan share of voice yang ada di media sosial. Dengan ini, UGC dapat membantu organik konten yang disebarkan selain melalui akun resmi. Karena forecasting kehumasan yang dilakukan oleh Prof. Dr. Ana Ardi dari Universitas Quadriga yang berjudul "Trends, competences and solutions for the near future of PR/ Communications" (2019) menunjukan adanya tren teknologi yang akan berlangsung hingga tahun 2025: (1) Big
Data Analysis yang akan membantu memahami analisa data yang berimbas kepada perubahan komunikasi; Artificial Intelligence: membantu distribusi melalui otomasi konten kepada khalayak maupun individual; (3) Social Bot: Dengan adanya otomasi, maka bot sangat mungkin dapat mendominasi dan memiliki kekuatan untuk membentuk wacana dan pendapat yang berujung pada produk dan layanan mereka; (4) Software Collaboration: Teknologi yang mendukung kecepatan untuk organisasi atau perusahaan untuk bekerja lebih efektif. Dari prediksi di atas tidak memungkinkan UGC memiliki peran cukup penting dalam mengakali otomasi yang dijalankan oleh mesin penghitung algoritma media sosial.

\section{Implikasi kepada Praktisi}

Menurut NV, UGC juga memiliki nilai tambah dari segi media, dan berkontribusi besar dalam mendapatkan share of voice yang dimungkinkan lebih tinggi dibandingkan unggahan berbayar maupun kampanye dengan sponsor brand. Definisi dari share of voice sendiri menurut Sproutsocial.com adalah pengukuran yang membandingkan pasar yang dimiliki oleh brand dan kompetitor yang salah satunya melihat seberapa besar perbincangan di industri didominasi oleh 
suatu brand. Sehingga peran UGC disini bukan sebagai bonus komunikasi belaka dalam meningkatkan kesadaran, namun juga meningkatkan porsi eksistensi brand dalam ekosistem media sosial. Dengan memperbanyak UGC yang terkait dengan brand maupun kata kunci yang relevan, $\mathrm{NV}$ berpendapat hal ini dapat berpengaruh kepada digital cloud pada sosial media. Walaupun UGC sebagai E-WOM memerlukan faktor lain. Namun untuk menjadikannya sebagai salah satu strategi utama, kedua informan memiliki pendapat yang berbeda-beda. Selain branding yang kuat, menurut FV yang diperlukan bagi para pelaku industri makanan dalam memanfaatkan UGC adalah menjalankan fase yang tepat yakni perkenalan, peluncuran dan lanjutan yang mana termasuk memberikan contoh produk secara organik dengan UGC dapat menjadi alternatif untuk melakukan E-WOM di dunia digital khususnya media sosial. Hal ini juga berkaitan apabila adanya brand yang memiliki biaya komunikasi sedikit, maka opsi UGC patut diperhitungkan sebagai strategi komunikasi yang dapat diibaratkan sebagai perpanjangan tangan dari brand. Mengandalkan UGC merupakan alternatif untuk para usaha kecil menengah untuk terlihat di media sosial.
Sedangkan menurut NV, yang diperlukan untuk sebuah brand dalam memanfaatkan UGC juga adalah strategi yang membuat produk lebih bernilai dari sekedar makanan. Seperti contohnya adalah dengan melihat kolaborasi yang diciptakan oleh Indomie dengan Haluu, salah satu tempat swafoto dengan dekorasi kekinian yang sangat kekinian di kalangan generasi milenial dan gen z (Kumparan, 2019). Kualitas, relevansi dan emosi yang diberikan pada UGC akan lebih tinggi ketika suatu brand hadir memberikan nilai yang berarti bagi khalayak di komunitas virtual. UGC juga dapat diukur dengan melakukan social media listening, bukan hanya untuk melihat suatu tren atau krisis untuk melakukan strategi komunikasi terhadap publik di dunia digital namun juga evaluasi dan mengukur berdasarkan standar yang ditetapkan kampanye atau pesan yang disampaikan (Tam \& Kim, 2019). Hal ini juga digunakan sebagai salah satu cara untuk mengantisipasi komentar negatif yang dilontarkan melalui UGC yang dapat sedikit banyak mempengaruhi kampanye digital yang berlangsung.

\section{Simpulan}

Dalam era web partisipatif, peran pengguna tidak lagi sebagai konsumen namun juga sebagai pembuat konten. 
Algoritma media sosial yang terkadang berubah-ubah membuat brand harus memiliki banyak strategi komunikasi termasuk memasukan peran UGC sebagai E-WOM. Dalam penelitian ini, peran UGC pada E-WOM terlihat jelas pada fungsi penyebar informasi dan cocommunicating. Kedua peran tersebut merupakan peran awal UGC untuk mendorong rasa penasaran dan ingin tahu lebih banyak dari sesama pengguna media sosial di dalam ekosistem digital. Strategi komunikasi ini bertujuan antara lain untuk membangun kedekatan antara brand dan khalayak secara organik serta untuk menjangkau lebih banyak khalayak melalui akun pengunggah UGC. Yang \& Mutum (2015) mengungkapkan komunikasi termediasi komputer ini dapat memberikan informasi lebih jelas dan terpercaya dengan konten organik yang dibuat oleh sesama pengguna. Hal ini juga dikarenakan adanya faktor emosional yang ditanamkan dalam UGC tersebut. Walaupun motivasi melakukan UGC dapat berbeda-beda, terutama untuk kepentingan sosial dan sebagai salah satu pembuktian kepada komunitas virtual. Banyaknya UGC yang diunggah dengan kata kunci relevan akan mewujudkan share of voice yang tinggi di digital cloud. Maka penggunaan UGC akan sangat berguna bagi para pelaku industri makanan yang memiliki biaya terbatas ataupun ingin mencoba menjangkau pengguna dengan berbagai latar belakang. Strategi ini dapat dimulai dengan melakukan branding yang tidak hanya sekedar menyajikan makanan, namun juga menyajikan relevansi terutama momen dan tren yang ada di sekitar pengguna. Relevansi menjadi satu hal yang penting untuk membangun kualitas dan kuantitas UGC terutama ketika inovasi dari kompetitor mulai merambah ke ranah UGC.

Lalu secara eksklusif, brand dapat memberikan produk secara cuma-cuma kepada para pengguna aktif media sosial. Namun penggunaan UGC ini juga beresiko karena kontrol yang ada di luar brand. Pemilihan UGC sebagai E-WOM juga sedikit banyak dapat dipengaruhi oleh brand seperti melakukan sortir kepada pengguna yang akan dikirimkan berdasarkan tiga hal: (1) dampak dari media sosial mereka; (2) jumlah pengikut media sosial; dan pilihan terakhir adalah (3) persentase dari keterlibatan pengguna dengan pengikut media sosial. Walaupun tidak dapat dipungkiri, kemungkinan dampak negatif yang akan terjadi informasi yang kurang jelas hingga munculnya komentar negatif yang dapat membuat krisis komunikasi. Disinilah 
diperlukannya melakukan social media listening yang rutin untuk mencegah krisis komunikasi di masa depan.

Diharapkan di penelitian selanjutnya dapat membahas bagaimana suatu UGC dapat diukur melalui share of voice. Karena seiring dengan penelitian ini muncul konsep share of voice sendiri belum terlalu di dalami jurnal yang masih terbatas dan masih erat kaitannya dengan Search Engine Optimization (SEO) yang secara luas ada di ranah situs, buka media sosial berbasis aplikasi seperti Instagram.

\section{Daftar Pustaka}

Blackshaw, P., \& Nazzaro, M. (2006). Consumer-Generated Media ( CGM ) 101 Word-of-Mouth in the Age of the Web-Fortified Consumer. Nielsen BuzzMetrics White Paper, $1-13$.

Clarke, V. and Braun, V. (2013) Successful qualitative research: A practical guide for beginners. London: Sage. ISBN 9781847875815

Creswell, J. W. (2013). Data Analysis Workshop. Research Design qualitative quantitative and mixed methods approaches, 1(9), 270. https://doi.org/10.1017/CBO978110 7415324.004

Dahlander, L., Frederiksen, L., \& Rullani, F. (2008). Online communities and open innovation: Governance and symbolic value creation. Industry and Innovation, 15(2), 115-123. https://doi.org/10.1080/1366271080 1970076
Daugherty, T., Eastin, M. S., \& Bright, L. (2008). Exploring Consumer Motivations for Creating UserGenerated Content. Journal of Interactive Advertising, 8(2), 16-25. https://doi.org/10.1080/15252019.2 008.10722139

Delafrooz, N., Rahmati, Y., \& Abdi, M. (2019). The influence of electronic word of mouth on Instagram users: An emphasis on consumer socialization framework. Cogent Business and Management, 6(1), 114.

https://doi.org/10.1080/23311975.2 019.1606973

Ekhlassi, A., Nezhad, M. H., Far, S. A., \& Rahmani, K. (2012). The relationship between brand personality and customer personality, gender and income: A case study of the cell phone market in Iran. Journal of Targeting, Measurement and Analysis for Marketing, 20(3-4), 158-171. https://doi.org/10.1057/jt.2012.12

Germon, R., Sokolova, K., \& Bami, A. (2017). Analyzing User Generated Content on Instagram: the Case of Travel Agencies. PATTERNS 2017: The Ninth International Conference on Pervasive Patterns and Applications, c, 78-81

Grid. (2019, May 21). Terungkap Kado Spesial dari Indomie untuk Ulang Tahun Chitato ke-30 Tahun. https://www.grid.id/read/041733281 /terungkap-kado-spesial-dariindomie-untuk-ulang-tahun-chitatoke-30-tahun?page=2.

Hennig-Thurau, T., \& Walsh, G. (2003). Electronic word-of-mouth: Motives for and consequences of reading customer articulations on the internet. International Journal of Electronic Commerce, 8(2), 51-74. 
https://doi.org/10.1080/10864415.2 003.11044293

Hsiao, T. T., \& Chuang, S. T. (2009). The role of virtual community in disseminating electronic word of mouth. 2009 Joint Conferences on Pervasive Computing, JCPC 2009, 755-760.

https://doi.org/10.1109/JCPC.2009. 5420083

IAB. (2008). IAB Platform Status Report: User Generated Content, Social Media, and Advertising [An Overview].

Ingrosso, L., Schmidt, T., Sherally, J., Dembech, M., Montes, S. B., Machado, R. S., ... Severoni, S. (2015). A desk review on institutional and non-institutional organizations active in the field of migrant's health in the WHO European Region. Ann Ist Super Sanità, 47(4), 313-320. https://doi.org/10.4415/ANN

Kumparan (2019, December 13). Jadi Mi Terenak di Dunia, Ini 4 Alasan Indomie Disukai Banyak Orang. https://kumparan.com/kumparanfoo d/jadi-mi-terenak-di-dunia-ini-4alasan-indomie-disukai-banyakorang-1sR1nQJ3wnF

Kaplan, A. M., \& Haenlein, M. (2010). Users of the world, unite! The challenges and opportunities of Social Media. Business Horizons, 53(1), 59-68. https://doi.org/10.1016/j.bushor.200 9.09.003

Kaufmann, K., \& Peil, C. (2020). The mobile instant messaging interview (MIMI): Using WhatsApp to enhance self-reporting and explore media usage in situ. Mobile Media and Communication, 8(2), 229-246. https://doi.org/10.1177/2050157919 852392

Khajuria, I. (2017). A Study of UserGenerated Content on Social
Networking Sitesand its Impact on Consumer-Based Brand Equity Constructs. 17(1).

Kumparan. (2019). Jadi Mi Terenak di Dunia, Ini 4 Alasan Indomie Disukai Banyak Orang. Kumparan. https://kumparan.com/kumparanfoo d/jadi-mi-terenak-di-dunia-ini-4alasan- indomie-disukai-banyakorang-1sR1nQJ3wnF

Laestadius, L. I., \& Wahl, M. M. (2017). Mobilizing social media users to become advertisers: Corporate hashtag campaigns as a public health concern. Digital Health, 3, 205520761771080.

https://doi.org/10.1177/2055207617 710802

LA Times (2019, November 5) The official instant ramen power rankings.

https://www.latimes.com/food/story /2019-11-05/instant-ramen-powerrankings-lucas-peterson

Lin, H. C., \& Chang, C. M. (2018). What motivates health information exchange in social media? The roles of the social cognitive theory and perceived interactivity. Information and Management, 55(6), 771-780. https://doi.org/10.1016/j.im.2018.03 .006

Lobato, R., Thomas, J., \& Hunter, D. (2012). Histories of user-generated content: Between formal and informal media economies. Amateur Media: Social, Cultural and Legal Perspectives, 5, 3-17. https://doi.org/10.4324/9780203112 021

Malthouse, E. C., Calder, B. J., Kim, S. J., \& Vandenbosch, M. (2016). Evidence that user-generated content that produces engagement increases purchase behaviours. Journal of Marketing Management, 32(5-6), 427-444. 
https://doi.org/10.1080/0267257X.2 016.1148066

Mix (2017) INDOMIE, THE FIRST INDONESIA's BRAND IN TOP-10 GLOBAL BRAND. https://mix.co.id/marcomm/brandcommunication/indomie-firstindonesian-brand-top-10-globalbrand/

Mohammad, J., Quoquab, F., Thurasamy, R., \& Alolayyan, M. N. (2020). The Effect of User-Generated Content Quality on Brand Engagement: The Mediating Role of Functional and Emotional Values. Journal of Electronic Commerce Research, 21(1), 39.

Moleong, L. (2001) Metode Penelitian Kualitatif. Bandung; Remaja Rosdakarya

Muntinga, D. G., Moorman, M., \& Smit, E. G. (2011). Introducing COBRAs: Exploring motivations for BrandRelated social media use. International Journal of Advertising, 30(1). https://doi.org/10.2501/IJA30-1-013-046

Mustonen, P. (2009). Social Media a New Way To Success. http://info.tse.fi/julkaisut/kr/Kre1_2 009.pdf

NapoleonCat (2020, January 16). Instagram users in Indonesia January 2020 https://napoleoncat.com/stats/instagr am-users-in-indonesia/2020/01

NapoleonCat (2020, January 16). Instagram users in Indonesia January 2020 https://napoleoncat.com/stats/instagr am-users-in-indonesia/2020/01

O’Hern, M. S., \& Kahle, L. R. (2013). The Empowered Customer: UserGenerated Content and the Future of Marketing. Global Economics and Management Review, 18(1), 22-30. https://doi.org/10.1016/s23401540(13)70004-5
Organisation for Economic Co-operation and Development . (2007). Participative Web and User-Created Content. DIRECTORATE FOR SCIENCE, TECHNOLOGY AND INDUSTRY COMMITTEE FOR INFORMATION, COMPUTER AND COMMUNICATIONS POLICY , 1-66. https://doi.org/10.1787/9789264037 472-en

Panahi, Sirous, Watson, Jason, \& Partridge, Helen (2012) Social media and tacit knowledge sharing: Developing a conceptual model. World Academy of Science, Engineering and Technology, 64, pp. 1095-1102.

Przybylski, A. K., Murayama, K., Dehaan, C. R., \& Gladwell, V. (2013). Motivational, emotional, and behavioral correlates of fear of missing out. Computers in Human Behavior, 29(4), 1841-1848. https://doi.org/10.1016/j.chb.2013.0 2.014

Rayinda, M. A. (2019). Pengaruh User Generated Content Terhadap Perilaku Para Foodie Pengguna Media Sosial. Jurnal Komunikasi Dan Kajian Media, 3(2), 116-127. http://jurnal.untidar.ac.id/index.php/ komunikasi/article/viewFile/1257/1 117

Rensink, J. . (Maarten). (2013). What motivates people to write online reviews and which role does personality play? July.

Sawhney, M., Verona, G., \& Prandelli, E. (2005). Collaborating to create: The internet as a platform for customer engagement in product innovation. Journal of Interactive Marketing, 19(4), 4-17. https://doi.org/10.1002/dir.20046

Stevanov, B., Gračanin, D., Suzić, N., \& Tešić, Z. (2017). Visibility of Industry 4.0 on social networks. 
XVII International Scientific Conference on Industrial Systems (IS'17), 1, 78-83.

Svensson, A. E. C. (2011). FACEBOOK the Social Newspaper that Never Sleeps. Master Degree, 2-16.

Tham, A., Croy, G., \& Mair, J. (2013). Social Media in Destination Choice: Distinctive Electronic Word-ofMouth Dimensions. Journal of Travel and Tourism Marketing, 30(1-2), 144-155. https://doi.org/10.1080/10548408.2 013.751272

Tirto. (2019, February 4). Indomie HypeAbis, Pemasaran Kekinian untuk Generasi Kiwari - Tirto.ID. https://tirto.id/indomie-hypeabispemasaran-kekinian-untukgenerasi-kiwari-dfSF
Wang, Y., \& Rodgers, S. (2010). Electronic word of mouth and consumer generated content: From concept to application. Handbook of Research on Digital Media and Advertising: User Generated Content Consumption, January 2015, 212-231. https://doi.org/10.4018/978-160566-792-8.ch011

Yang, H.-P. (Sophie), \& Mutum, D. S. (2015). Electronic Word-of-Mouth for University Selection. In Journal of General Management (Vol. 40, Nomor 4, hal. 23-44). https://doi.org/10.1177/0306307015 04000403

Yap, K. B., Soetarto, B., \& Sweeney, J. C. (2013). The relationship between electronic word-of-mouth motivations and message characteristics: The sender's perspective. Australasian Marketing Journal, 21(1), 66-74. https://doi.org/10.1016/j.ausmj.2012 .09 .001 